\title{
Evidence by means of closed circuit television or similar electronic media in South Africa: Does section 158 of the Criminal Procedure Act have extra- territorial application?
}

Jamil Ddamulira Mujuzi

LLB (Hons) LLM LLM LLD

Associate Professor of Law, Faculty of Law, University of the Western Cape

\section{OPSOMMING}

Getuienis deur middel van Geslotekringtelevisie of Soortgelyke Media in Suid Afrika - Het Artikel 158 van die Strafproseswet Ekstra-territoriale

Toepassing?

Artikel 158(2) van die Strafproseswet 51 van 1977 bepaal onder andere dat 'n Hof op eie inisiatief of op aansoek van die aanklaer, die beskuldigde of 'n getuie kan gelas dat die beskuldigde of getuie, indien die beskuldigde of getuie daartoe instem, deur middel van geslotekringtelevisie of soortgelyke elektroniese media getuig. Regspraak, insluitend appèlhof gesag, toon aan dat artikel 158 ook aangewend is in die verlede vir getuies wat buite Suid Afrika gesetel is ten einde getuienis af te lê deur middel van geslotekringtelevisie tydens 'n verhoor in Suid Afrika. In hierdie bydrae word daar aangetoon dat hierdie praktyk foutief is met spesifieke verysing na geskiedenis ten aansien van die opstel van artikel 158.

\section{Introduction}

Section 158 of the Criminal Procedure Act $^{1}$ provides that:

(1) Except as otherwise expressly provided by this Act or any other law, all criminal proceedings in any court shall take place in the presence of the accused.

(2)(a) A court may, subject to section 153, on its own initiative or on application by the public prosecutor, order that a witness or an accused, if the witness or accused consents thereto, may give evidence by means of closed circuit television or similar electronic media. (b) A court may make a similar order on the application of an accused or a witness.

(3) A court may make an order contemplated in subsection (2) only if facilities therefor are readily available or obtainable and if it appears to the court that to do so would- (a) prevent unreasonable delay; (b) save costs; (c) be convenient; (d) be in the interest of the security of the State or of public safety or in the interests of justice or the public; or (e) prevent

$1 \quad$ Criminal Procedure Act 51 of 1977 . For a discussion of evidence by means of electronic media in civil matters, see Uramin Incorporated $v$ Perie (28154/ 2011) 2013 (GPJHC) 314 (2013-12-11).

How to cite: Mujuzi ‘Evidence by means of closed circuit television or similar electronic media in South Africa: http://dx.doi.org/10.17159/2225-7160/2015/v48n1a1 
the likelihood that prejudice or harm might result to any person if he or she testifies or is present at such proceedings.

(4) The court may, in order to ensure a fair and just trial, make the giving of evidence in terms of subsection (2) subject to such conditions as it may deem necessary: Provided that the prosecutor and the accused have the right, by means of that procedure, to question a witness and to observe the reaction of that witness.

Section 158 was introduced into the Criminal Procedure Act in 1996 by the Criminal Procedure Amendment Act. ${ }^{2}$ The Criminal Procedure Amendment Act was assented to by the South African President on 6 November 1996 and commenced on 26 November 1996 - the day on which it was published in the government gazette. ${ }^{3}$ One of the purposes of the Criminal Procedure Amendment Act, as stated in the long title, is "to provide that evidence may be given by means of closed circuit television or similar electronic media". This means that the accused or the witness does not have to be physically present in court if section 158 is invoked. Before section 158 was inserted into the Act, a witness had to be present physically or give evidence on commission ${ }^{4}$ or by affidavit. ${ }^{5}$ If a witness is physically present in court, the accused has a right to crossexamine him, ${ }^{6}$ unless such a witness is subpoenaed by the court in which case the court's consent is needed before the accused or the prosecutor may cross-examine such a witness. ${ }^{7}$ If a witness gives evidence on commission, he may still be examined by the accused or the state. ${ }^{8}$ Section 158 introduces a mechanism through which a witness or accused may give evidence by means of close circuit television or similar electronic media. It is important to note that underlying section 158(2) is the assumption that the witness or the accused is "present" in court, but through a monitor. This is supported by the fact that it is the presiding officer who administers the oath to the witness or the affirmation or to admonish the witness to speak the truth. ${ }^{9}$ If a witness misconducts himself while giving evidence through closed circuit television or similar electronic media, he could be prosecuted for contempt of court. However, South African courts, including the Supreme Court of Appeal, have held that a witness who is based abroad may give evidence through

2 Criminal Procedure Amendment Act No 86 of 1996

3 Government Gazette No 1884 1996-11-20. However, section 158 came into operation on 1997-09-01. See Schwikkard \& Van der Merwe Principles of Evidence (2008) 390.

4 See s 171 of the Criminal Procedure Act.

$5 \quad$ Idem s 212

$6 \mathrm{~S} 35(3)$ (i) of the Constitution provides that the accused has the right to adduce and challenge evidence. Courts have held that s 35(3)(i) embodies the accused's right to cross-examine state witnesses. See $S v$ Msimango and another 2010 (1) SACR 544 (GSJ) par 27; and S v Ngudu 2008 (1) SACR 71 (N) par 24.

$7 \quad$ S 186 of the Criminal Procedure Act.

8 Idem s 172

9 See for example, $S v$ Ncedani 2008 JOL 22342 (Ck) where a child witness gave evidence through an intermediary and through closed circuit television. 
closed circuit television or similar electronic media under section 158. In Mclaggan v S, ${ }^{10}$ the Supreme Court of Appeal held that the High Court had correctly relied on section 158(2) to receive the evidence of witnesses who were based abroad. ${ }^{11}$ The purpose of this article is to argue that section 158(2)-(4) was not designed to be invoked as a tool, through which a witness based abroad may give evidence before a South African court. It is argued that evidence obtained through section 158(2) from a witness based abroad, is improperly obtained and impacts on the fairness of the trial. Before I embark on the task of illustrating that section $158(2)$ - (4) should not be invoked to obtain evidence from a witness based abroad, it is imperative to highlight some of the issues that courts have dealt with in their application of section 158(2).

\section{Section 158(2) in Practice}

Section 158(2) has been applied to adult and child witnesses. Where it has been applied to child witnesses, intermediaries have also been appointed by the court. Section 170A of the Criminal Procedure Act empowers a court to appoint an intermediary in certain circumstances. ${ }^{12}$ In $S v$ Motaung, a child witness was sworn in and she "gave evidence in terms of sections 158(2)(a) and 170A(3)(c) of the Criminal Procedure Act in a room outside the court through the medium of closed circuit television". ${ }^{13}$ In $S v$ Sindane, ${ }^{14}$ the applicant was convicted of raping a 13-year old girl and sentenced to 18 years' imprisonment. The complainant gave evidence by means of closed circuit television and the applicant applied for leave to appeal, against his conviction and sentence, on the ground that the requirements under section 158(2)-(4) were not complied with during the trial. He argued that the magistrate had ordered the complainant to give evidence through closed circuit television:

[i] without enquiring from her whether she is prepared to consent thereto as required in section 158(2) of the Act and satisfying himself that the requirements of section $158(3)$ of the Act had been met by the prosecution;

[ii] failing to appreciate that the requirements set out in section 158 (3)(a) of the Act ...

10 McLaggan v S 2013 JOL 30559 (SCA); S v Mclaggan 2013 JDR 1359 (SCA).

11 Idem par 38.

12 S $170 A(1)$ provides that: "Whenever criminal proceedings are pending before any court and it appears to such court that it would expose any witness under the biological or mental age of eighteen years to undue mental stress or suffering if he or she testifies at such proceedings, the court may, subject to subsection (4), appoint a competent person as an intermediary in order to enable such witness to give his or her evidence through that intermediary".

13 S v Motaung (ECJ 079/2005) 2005 (ECHC) 33 (2005-10-19) par 9.

14 Sv Sindane (CC 166/04) 2008 (NWHC) 34 (2008-09-12). 
[iii] failing to appreciate that the words "if it appears to the court" in section 158 (3) of the Act connote a degree of proof not lower than that of proof on a balance of probabilities;

[iv] failing to appreciate that the mere statement of the representative of the State ... could not be persuasive enough to enable him to make a finding on a balance of probabilities that the requirements of the Act had been met and more particular [sic] that the complainant would be exposed to harm or prejudice were she to testify in the normal course as contemplated in section 158(3)(e) of the Act;

[v] not satisfying himself that the application was not being made on trivial grounds;

[vi] not exercising the discretion giving to him in section 158 in a proper and judicial manner; and

[vii] failing to ensure a fair and just trial by not imposing conditions as envisaged in section 158(4) of the Act. ${ }^{15}$

In dismissing the application, the High Court held that "[s]ection 158(3) gives the court a discretion and the court may make an order in terms of sub-section (2) 'on its own initiative or on application by the public prosecutor ... in the interest of justice". 16 The Court added that the prosecutor's application to the magistrate to invoke section 158(2)(4) was clear that "the court environment [was] not a familiar place" for the witness and that she would be "free and comfortable to testify, to give evidence in a separate room from the court." 17

Another issue that emerged in applying section 158(2)-(4), is whether the requirements in section 158(3) should be read disjunctively. Cases dealing with this issue are discussed below. Central to this article is the question of whether or not section 158(2)-(4) may be invoked to enable a witness, who is based abroad, to give evidence in a South African court. South African courts have taken two opposed approaches on whether or not section 158(2)-(4) may be invoked for a witness based abroad to give evidence before a South African court. The author is aware of four court decisions on this issue. Three different court decisions, including a Supreme Court of Appeal decision, have held that section 158(2)-(4) may be invoked by a witness based abroad to give evidence before a South African court. One High Court decision is to the effect that section 158(2)(4) may not be invoked for that purpose. In the light of the fact that the principle of precedent, or stare decisis, obliges the High Court to follow the decisions of the Supreme Court of Appeal, ${ }^{18}$ the legal position in

15 Idem par 3

16 Idem par 4

17 Idem par 5. In S v Kimeze and Others (SS33/2009) 2013 (WCHC) 48 (201302-25), the High Court dismissed the prosecution's application for some of the state witnesses to give evidence by electronic media because "the state failed to indicate what form the electronic media would take and how long the trial would be delayed for that media to be set up" (par 8).

18 For a detailed discussion of this principle see du Bois (ed) Wille's Principles of South African Law (2007) 76 - 99. See also Media 24 Ltd and Others $v$ SA Taxi Securitisation (Pty) Ltd 2011 (5) SA 329 (SCA) parr 33-34. 
South Africa is that section 158 (2)-(4) may be invoked to obtain evidence from a witness based abroad. The discussion below highlights the different court decisions mentioned above in the order in which they were handed down.

As far as I could ascertain, $S v F^{19}$ was the first case in which the question of whether section 158(2)-(4) is applicable to a witness who was based abroad was dealt with, albeit obiter. The state made an application for a seventeen year old complainant in a rape, assault and abduction trial, who was in the court's jurisdiction, to give evidence by means of closed circuit television. The central issue before the court was whether the grounds in section 153(3) had to be considered conjunctively. The Court observed that:

A good example of a situation that could very well find application under subsection 3(a), (b) and (c) would be of a witness who is bedridden in a London hospital. One could easily imagine that to await the recovery, if at all, of this witness might give rise to unreasonable delay in bringing the matter to a speedy conclusion. Even if arrangements could be made for her in her bedridden state to be brought to court in South Africa it might prove costly. To afford a witness in this position the facility of giving evidence by means of closed circuit television or similar electronic media, might very well under such circumstances prove to be convenient for all concerned. One would have thought that the presence of these three factors would have been sufficient for the obtaining of an order in terms of section 158. However, the legislature in its wisdom clearly stipulated that any of the further requirements set forth in paragraphs (d) or (e) of subsection (3), of which there is quite a number, must also be complied with. Thus, on the example postulated above, a case for an order in terms of section 158 might very well be made out if it is shown that in allowing the witness to give evidence by means of closed circuit television or similar electronic media, that not only will unreasonable delay be avoided, costs saved, it will be convenient to all concerned (as required in terms of subsection (3)(a), (b) and (c)) but, in addition thereto, it will - for example be in the interests of justice (as required in terms of paragraph $3(\mathrm{~d})$ ). ${ }^{20}$

In $S v$ Staggie and another, ${ }^{21}$ the High Court disagreed with the reasoning in $S v F$ to the effect that the grounds in section 158(3) had to be considered conjunctively. The Court held that the various paragraphs "must be read disjunctively". 22 However, the Court did not dispute the observation in $S v F$ that section 158(3) could be invoked in the case of a witness who is bedridden in a London hospital. In $S v$ Domingo ${ }^{23}$ the full bench agreed with the reasoning in $S v$ Staggie and another that the grounds in section 158(3) must be read disjunctively. However, the Court went further and overruled the decision $S v F$ "insofar as it relates to the meaning and interpretation of section 158" because it was "clearly wrong" and that "the provisions of [section 158(3)] must be read

$19 S$ S F 1999 (1) SACR 571 (C).

20 Idem par 578.

21 Sv Staggie and another 2003(1) SACR 232(C).

22 Idem par 248.

23 S v Domingo 2005 (1) SACR 193 (C). 
disjunctively". ${ }^{24}$ Like in $S v$ Staggie and another, the Court in $S v$ Domingo did not take issue with the observation in $S v F$ that section 158 may be invoked to obtain evidence from a witness who is bedridden in a London hospital. As stated above, this could be because of the fact that the witness in question was based in South Africa, and the issue of whether or not evidence could be obtained from a witness who is based abroad did not directly arise in the case. However, the courts' silence on that issue cannot go unnoticed.

In the case of Lawrence Goldberg and another $v$ Magistrate R Boshoff NO and another ${ }^{25}$ the issue of whether section 158 could be invoked to enable a witness based abroad to testify in criminal proceedings in a South African court arose. The applicants were on trial in a magistrate's court for various offences, including fraud. The state made an application in terms of section 2(1) of the International Co-operation in Criminal Matters Act (ICCMA; this section will be discussed later in this article) for the witnesses based in the United Kingdom to give evidence on the basis of section 158(2)-(4) of the Criminal Procedure Act. The magistrate allowed the state's application and ruled that the relevant authorities in the United Kingdom should be requested to:

[Secure] the attendance of the ... witnesses at a venue in the United Kingdom from where the court ... sitting in [South Africa], would receive their evidence by means of electronic media equipment. The witnesses [were] to be examined, cross-examined, and re-examined by electronic means from the court room in [South Africa]. ${ }^{26}$

The applicant approached the High Court and argued that the magistrate had erred in making that order. The High Court unanimously agreed with the applicants and held that:

The learned regional magistrate has no authority, either in terms of the provisions of s[ection] 2(1) of the ICCMA or in terms of the provisions of s[ection] 158 of the CPA, to issue a letter of request in which the relevant authorities in the United Kingdom are requested to arrange and facilitate the attendance of witnesses at a venue in the United Kingdom from where they, by electronic means, would give their evidence at the proceedings in the court a quo. Such power and procedure cannot be read into the clear wording of these statutory provisions. ${ }^{27}$

The Court added that:

The relevant provisions of the ICCMA permit the examination at proceedings in the foreign state of a person who is in the foreign state, if the evidence of such person is 'necessary in the interests of justice' in the proceedings before a court of this country and 'the attendance of such person cannot be obtained without undue delay, expense, or inconvenience'. Judicial authorisation to

24 Idem par 199.

25 Lawrence Goldberg and another $v$ Magistrate R Boshoff NO and another Case No 09/53076 (2010-07-30).

26 Idem par 2.

27 Idem par 13. 
request this form of assistance from a foreign state is required and is given when a court issues a letter of request. The law and procedure of the foreign state apply to the proceedings at the examination of the witness abroad. Such proceedings at which the witness is examined are not proceedings of the court which issued the letter of request. The evidence obtained at such proceedings is admitted as evidence by the court which issued the letter of request '... in so far as it is not inadmissible at such proceedings'.

The provisions of s[ections] 158(2) - (5) of the CPA concern the giving of evidence by an accused or by a witness through closed circuit television or similar electronic media at local proceedings in a criminal court and the circumstances under which the court may order that the evidence be given through such media. These provisions do not permit a procedure for the taking of evidence across borders by electronic means at a local criminal trial. Nothing in these subsections suggest an '... arrangement or practice for the provision or obtaining of international co-operation in criminal matters' as was submitted to us by the second respondent's counsel. ${ }^{28}$

In Lawrence Goldberg and another $v$ Magistrate $R$ Boshoff $N O$ and another, the High Court makes it very clear that section 158 of the Criminal Procedure Act cannot be invoked in relation to a witness who is based abroad. This is the case even if the authorities in a foreign country are willing to ensure that those witnesses give that evidence on the basis of a letter of request issued by a South African court. In the cases discussed so far, witnesses based abroad did not testify on the basis of section 158 of the Criminal Procedure Act. In other words, section 158 was not put in practice.

However, the situation was to change in 2012. In Sv Mclaggan ${ }^{29}$ the accused was convicted of raping an eighteen year old British woman who was visiting South Africa to participate in a youth programme in which the accused was also involved. The High Court allowed the state's applications for the evidence of experts, based in the United Kingdom, to be led through a video-link on the basis of section 158 of the Criminal Procedure Act. This is because the witnesses were too busy to travel to South Africa. The first witness was a medical specialist paediatrician and endocrinologist (Dr Spoudeas) who gave evidence at the trial. The second witness was a neuro-psychologist (Ms Smit) who gave evidence at sentencing. Both experts were familiar with the mental state of the complainant before and after the rape. On the issue of Dr Spoudeas' evidence, the prosecution submitted that:

[I]n the event that the application [to give evidence on the basis of section 158] was not granted it would inevitably result in a delay in the finalisation of the trial. The presentation of the evidence by way of a video conference link where there was a readily available facility to enable such link, would be both convenient and in the circumstances of the matter would result in a saving of costs. On this basis it was contended that it was in the interests of justice that the evidence be presented by way of a video conference link. ${ }^{30}$

28 Idem parr 15-16. Footnotes omitted

29 S v McLaggan (CC70/2011) 2012 (ECGHC) 63 (2012-08-20).

30 Idem par 70. 
The accused's lawyer opposed the application on the basis that:

$[T]$ he fundamental requirement of fairness required that the accused be entitled to confront any witness who would testify and that the inroad into this right should be permitted only in exceptional circumstances. This required that the court should consider the nature of the evidence to be given. Where such evidence was irrelevant or where its probative value in relation to essential matters in dispute is limited, the deviation from the requirement that the proceedings be in the presence of the accused should not be permitted. 31

\section{The Court observed that:}

The presentation of the evidence by way of a video link should not lightly be permitted. A court called upon to consider such an application must consider carefully the basis upon which the application is made and the requirements as set out in section 158 (3) and, in my view, must also give consideration to the nature of the evidence sought to be tendered. ${ }^{32}$

The Court agreed with the reasoning in $S v$ Domingo that the requirements in section 158 of the Criminal Procedure Act should be considered disjunctively. ${ }^{33}$ It observed that "[a] paramount consideration in determining an application made in terms of section 158(2) are the interests of justice". 34 The Court added that it allowed Dr Spoudeas to present her evidence "by way of a video conference link" because she had "treated the complainant over a number of years and is highly familiar with both the nature of the complainant's condition and the effect that such condition may have upon the complainant." ${ }^{35}$ The Court added that:

I was satisfied that in the event that the application was not granted that there will be an unnecessary and undue delay in the finalisation of the matter and that this could reasonably and properly be avoided by the presentation of the evidence via a video link. I was informed from the Bar that the nature of the electronic video link would be such that the accused and counsel and the court would be able to observe the witness and that there would be an immediate video and audio link allowing for questions to be addressed to the witness and the witness' responses to be noted and observed. The witness too would be in a position to see via video link the court and all of the protagonists. The immediacy of the exchange would therefore allow for an appropriate level of interaction in order to ensure that the accused and his counsel are afforded an opportunity to confront the witness in crossexamination. In the light of this I was satisfied that the presentation of the evidence via video link would not unduly prejudice the accused in his defence. I was satisfied too that the nature of the evidence is such, given its expert nature, which is foreshadowed in written reports made available to the accused, that being presented via video conference link would not result in a breach of the accused's right to a fair trial in his presence. I was accordingly

31 Idem par 71

32 Idem par 72

33 Idem par 73

34 Idem par 74

35 Idem par 76 
satisfied that it would be in the interests of justice to have the evidence presented by way of a video conference link and I ruled accordingly ... 36

Dr Spoudeas gave her evidence through a video link and she was cross-examined by the defence and the court admitted her evidence and explained in detail why it was relevant to the trial. ${ }^{37}$ During sentencing, the Court also admitted the evidence of an expert, who was based in the United Kingdom, on the basis of section 158 of the Criminal Procedure Act. The prosecution's application “was motivated on the basis that Smit could give relevant evidence as to the psychological impact of the rape upon the complainant having assessed her and treated her as part of the team involved in her treatment as a young survivor of a brain tumour". 38 The defence's objection to the prosecution's application was based on "grounds similar to those raised in relation to an earlier similar application during the trial". 39 The Court held that:

In my view the nature of the evidence was clearly relevant and ought to be received. A sentencing court is concerned with formulating an appropriate and just sentence and is required to give consideration to a wide range of interests and factors. Evidence relating to the impact of the offence upon the victim is necessary. This matter involves a foreign national who is outside of the court's jurisdiction and it is therefore not easy to ensure the attendance of witnesses. Failure to receive the evidence by way of video link would not only result in an unnecessary and potentially lengthy delay to the prejudice of the accused but may also have had the effect that such evidence is ultimately not available to the court. In the light of these circumstances I considered that the use of the video link technology would not prejudice the accused having regard to the nature of the evidence. ${ }^{40}$

After that, the Court dealt with the evidence that Ms Smit adduced. It is important to note that the defence did not argue that section 158 was not applicable in this case. The reason for this is unclear. It should also be noted that in $S v$ Domingo, to which the court in this case referred with approval, the court did not deal with the issue of invoking section 158 with regards to a witness who is based abroad. In the application for leave to appeal to the Supreme Court of Appeal, the defence did not argue that the High Court had erred in invoking section 158 to receive evidence from abroad. The only instance in the application for leave to appeal in which the defence referred to section 158, was when it submitted that the High Court did not consider the fact that the accused was "running on a very limited budget" when it called specialist witnesses hence, by implication, denying the accused the opportunity to call experts to challenge their evidence. ${ }^{41}$ The High Court allowed the accused's application for leave to appeal to the Supreme Court of Appeal

36 Idem par 77.

37 Idem parr 78-84

38 S v McLaggan (CC70/2011) 2012 (ECGHC) 75 (2012-09-28) par 1.

39 Idem par 2

40 Idem par 3

41 S v McLaggan (CC70/2011) 2012 (ECGHC 78); 2013 (1) SACR 267 (ECG) (2012-10-04) par 9. 
against conviction, and the state's application to appeal against the sentence was also allowed. ${ }^{42}$ In $S v$ Mclaggan ${ }^{43}$ the Supreme Court of Appeal held, inter alia, that the appellant "wisely did not raise the objection [that the trial court should not have invoked section 158 for the witnesses to testify from the UK through video link] on appeal". 44 The Court added that the trial court "was correct in accepting the evidence of Dr Spoudeas" 45 and that of Ms Smit. ${ }^{46}$ The above jurisprudence shows that some High Court judges and the Supreme Court of Appeal judges, are of the view that section 158 of the Criminal Procedure Act may be invoked to enable a witness who is in a foreign country to give evidence by means of closed circuit television in a South African trial. I take issue with that approach and argue that section 158 is only applicable to witnesses who are based in South Africa. Below are the reasons in support of this argument.

\section{Reasons why Section 158 does not have Extra- Territorial Application}

The first reason why section 158 does not apply to witnesses based abroad, is that its drafting history is clear that it was meant to be limited to witnesses based in South Africa. It has been mentioned above that section 158 was introduced in the Criminal Procedure Act in 1996 by the Criminal Procedure Amendment Act. ${ }^{47}$ The Criminal Procedure Amendment Bill was one of the six Bills that the National Assembly debated (second reading) and passed on 31 October $1996 .{ }^{48}$ The Hansard show that all political parties unanimously supported all the Bills that were tabled before the National Assembly on that day. Many members made submissions of the various Bills before the National Assembly. It should be recalled that the Criminal Procedure Amendment Bill contained thirteen clauses ${ }^{49}$ and clause 7 was the one that amended

42 Idem par 17.

43 Sv Mclaggan supra n 10.

44 Idem par 35

45 Idem par 36

46 Idem par 38. See also parr $41-42 \& 50$.

47 Criminal Procedure Amendment Act supra $\mathrm{n} 2$

48 The other Bills were the International Co-operation in Criminal Matters Bill; the Proceeds of Crime Bill; Extradition Amendment Bill; Criminal Procedure Second Amendment Bill; and the Divorce Amendment Bill. See Debates of the National Assembly (Hansard), Third Session First Parliament, 15 January to 7 November 19964967.

49 The clauses dealt with the following issues: Clause one (admission of guilt and payment of fine after appearing in court); clause two (the rights of an accused); clause three (magistrate court referring the accused to a regional court for a summary trial); clause four (circumstances in which the prosecution may not be resumed or instituted); clause five (the court entering a plea of not guilty on behalf of the accused); clause six (empowering the regional court to ask the magistrates' court for a record of conviction if the former is of the opinion that the proceedings were not in accordance with justice); clause eight (courts regulating unreasonably 
the Criminal Procedure Act by inserting section 158 into the Act. Different members made submissions on different clauses of the Criminal Procedure Amendment Bill, but only three members made submissions on clause 7 . The first member to make submissions on clause 7 was Ms LB Ngwane who stated that:

Clause 7 of the Bill provides that criminal proceedings are to take place in the presence of the accused, but it also provides that a court may now order that evidence be given by means of closed-circuit television or similar electronic media if that will prevent delay, will save costs, is convenient, is in the public interest or the interests of the State or will prevent prejudice or harm to any person. 50

She went on to explain why "most trials take long to finalise". ${ }^{51}$ The second member to make submissions on clause 7 was Dr CP Mulder. He stated that:

Clause 7 of the Bill maintains the correct principle that all criminal proceedings should take place in the presence of the accused. The clause however, now provides for an exception without affecting the basic principle. Modern technological development makes it possible in certain cases to allow witnesses to give evidence or to prosecute an accused by way of closed-circuit television or other similar electronic devices, while they are not present, provided they agreed. ${ }^{52}$

The third and final member to make submissions on clause 7 was Dr FJ van Heerden. He stated that:

A new aspect which is to be welcomed is embodied in clause 7 , which seeks to amend section 158 of the principle Act in such a way that it creates an effective balance between the right of the accused to a fair trial and the possible humiliation or traumatic experience of a witness in rape or child molestation cases, for example, by making use of, inter alia, closed circuit television and other electronic media. ${ }^{53}$

Neither the Criminal Procedure Amendment Bill nor any member of the National Assembly expressly or impliedly stated that clause 7 could be invoked to obtain evidence from a witness based abroad. It should be noted that another important Bill that was read the second time and debated and passed on the same day as the Criminal Procedure Amendment Bill, was the International Co-operation in Criminal Matters Bill which would later become the International Co-operation in Criminal Matters Act. This Bill contained clause 2, which empowered a judge to issue a letter of request to obtain evidence from abroad. All the submissions that were made on the issue of obtaining evidence from

protracted cross-examination); clause nine (certificate or affidavit of an expert prima facie proof of the facts); clause ten (proof of undisputed facts); clause eleven (confessions); clause twelve (admissions); and clause thirteen (unreasonable delay in trials).

50 Debates of the National Assembly supra n 48 at 4992

51 Ibid.

52 Idem 4995

53 Idem 5029 
witnesses based abroad related to the International Co-operation in Criminal Matters Bill. ${ }^{54}$ For example, Mr WA Hofmeyer submitted that:

The first Bill [the International Co-operation in Criminal Matters Bill] is the one that deals with improving the co-operation between South Africa and other countries in obtaining evidence on criminal offences. The most important innovation in the law is to try to get around the rather cumbersome process of taking evidence on commission. The law now provides for judicial officers to issue a letter of request for evidence and for a speedy procedure to obtain that evidence from overseas. ${ }^{55}$

Another member, Mr MA Mzizi, submitted that:

The International Co-operation in Criminal Matters Bill is an attempt to enhance the effectiveness and co-operation between other prosecuting authorities and the South African prosecuting authority. We therefore welcome the introduction of a letter of request, a procedure whereby the Bill provides for obtaining evidence from foreign states. The current commission procedure in terms of the Criminal Procedure Act is cumbersome and not conducive to speedily and effectively obtaining overseas evidence. ${ }^{56}$

The above drafting history of section 158 makes it very clear that it was not meant to apply to witnesses based abroad. If a court wants to get evidence from a witness who is based abroad and the witness in question refuses, for whatever reason, to travel to South Africa and give evidence, that court has to invoke section 2 of the International Co-operation in Criminal Matters Act which provides that:

(1) If it appears to a court or to the officer presiding at proceedings that the examination at such proceedings of a person who is in a foreign State, is necessary in the interests of justice and that the attendance of such person cannot be obtained without undue delay, expense or inconvenience, the court or such presiding officer may issue a letter of request in which assistance from that foreign State is sought to obtain such evidence as is stated in the letter of request for use at such proceedings.

(2) A judge in chambers or a magistrate may on application made to him or her issue a letter of request in which assistance from a foreign State is sought to obtain such information as is stated in the letter of request for use in an investigation related to an alleged offence if he or she is satisfied- (a) that there are reasonable grounds for believing that an offence has been committed in the Republic or that it is necessary to determine whether an offence has been committed; (b) that an investigation in respect thereof is being conducted; and (c) that for purposes of the investigation it is necessary in the interests of justice that information be obtained from a person or authority in a foreign State.

(3) Subject to subsection (4), a letter of request shall be sent to the DirectorGeneral for transmission - (a) to the court or tribunal specified in the letter of request; or (b) to the appropriate government body in the requested State.

54 See for example, submissions by the Minister of Justice, Mr Dullar Omar; Debates of the National Assembly supra $n 48$ at 4975 .

55 Idem 4997-4998.

56 Idem 5021. 
(4)(a) In a case of urgency a letter of request may be sent directly to the court or tribunal referred to in subsection (3)(a), exercising jurisdiction in the place where the evidence is to be obtained, or to the appropriate government body referred to in subsection (3)(b).

(b) The Director-General shall as soon as practicable be notified that a letter of request was sent in the manner referred to in paragraph (a) and he or she shall be furnished with a copy of such a letter of request.

The Constitutional Court explained the difference between the procedure in section 2(1) and that in section 2(2). In Thint Holdings (Southern Africa) (Pty) Ltd and another $v$ National Director of Public Prosecutions, Zuma $v$ National Director of Public Prosecutions ${ }^{57}$ the Constitutional Court held that:

Under section 2(1), the letter of request is issued once it appears to the presiding officer during criminal proceedings that it is necessary in the interests of justice because a person who can give evidence cannot do so without undue expense, delay or inconvenience. The meaning of the section is clear: the letter of request is issued in court and not by a judge in chambers or a magistrate. The application is therefore made to the court by the investigator during, and not outside of, the criminal proceedings.

Section 2(2), however, requires a letter of request to be issued on application by an investigator outside of court proceedings. An application is made before a judge in chambers or a magistrate, thereby permitting a request to be made even before commencement of criminal proceedings and during investigations. $^{58}$

\section{The Court added that:}

For a letter of request to be granted, it is required that the judge or magistrate be satisfied that each of the jurisdictional requirements under section 2(2) has been met. Save for the question as to whether or not the information sought is necessary in the interests of justice, which under subsection 2(2)(c) is determined in the discretion of the judicial officer of the court, all the jurisdictional requirements are facts which must be proved. ${ }^{59}$

Therefore, for a witness to give evidence at the trial or at sentencing proceedings, section 2(1) of the International Co-operation in Criminal Matters Act is the applicable law. Of course this evidence could also be obtained through other bilateral or multilateral arrangements or agreements between South Africa and other countries. 60

Apart from the fact that the drafting history does not support the view that section 158 is applicable to witnesses based abroad, there are also other reasons as to why section 158 is only applicable to witnesses based in South Africa. Section 158 is silent on whether or not it is applicable to witnesses based outside South Africa. Had the legislature wanted section

572008 (2) SACR 557 (CC); 2009 (1) SA 141 (CC); 2009 (3) BCLR 309 (CC).

58 Idem parr 26-27.

59 Idem par 29.

60 See s 31 of the International Co-operation in Criminal Matters Act. 
158 to apply to witnesses based abroad, it would have expressly stated so. This is because there are sections in the Criminal Procedure Act in which the legislature has expressly stated that they apply to witnesses based abroad ${ }^{61}$ and section 158 is not one of them. Related to the above, is the settled principle of statutory interpretation in South African law that generally, "statutes are presumed not to operate extraterritorially". ${ }^{62}$ Where the legislature has intended that the legislation should operate extra-territorially, it has enacted specific provisions to that effect. ${ }^{63}$

The general rule, under section 158(1) of the Criminal Procedure Act read with section 35(3)(e) of the Constitution, is that the trial of the accused has to take place in his presence. ${ }^{64}$ Section 159 of the Criminal Procedure Act embodies express exceptions to that general rule. ${ }^{65}$ Jurisprudence emanating from South African courts ${ }^{66}$ and the drafting history of the Criminal Procedure Amendment $\mathrm{Act}^{67}$ suggest that section 158(2)-(4) creates an exception to the general rule under section 158(1) and section 35(3)(e) of the Constitution that the trial of the accused has to take place in his presence. The accused's or witness's consent is a prerequisite for section 158(2)-(4) to be applied. If section 158(2)-(4) is

61 See for example, s 212A on affidavits from abroad and s 272 on proving the accused's foreign previous conviction.

62 Minister of Law and Order, Kwandebele and others $v$ Mathebe and another 19904 All SA 98 (AD) par 13; and the earlier authorities referred to. See also Casino Enterprises (Pty) Limited (Swaziland) v Gauteng Gambling Board and others 2010 (6) SA 38 (GNP); 20111 All SA 305 (GNP) (South African gambling law does not regulate a gambling company registered in Swaziland although people based in South Africa could gamble online).

63 See for example, s 61 of the Criminal Law Sexual Offences and Related Matters Amendment Act 32 of 2007.

$64 \mathrm{~S} 35(3)(\mathrm{e})$ of the Constitution provides that every accused has a right "to be present when being tried".

65 In S v Khumalo 1991 (1) SACR 666 (NMS) the Court held that: "The section envisages three grounds which would entitle the court to order that criminal proceedings may take place in the absence of an accused, contrary to the fundamental rule that criminal proceedings may only take place in the presence of the accused ... The three exceptions to the general rule are: Where the court orders that an accused be removed if he conducts himself in a manner which makes the continuance of the proceedings in his presence impracticable (s 159(1)), or, secondly, where an accused makes application to be excused from the proceedings, and where such application is granted (s 159(2)(a)), read with s 159(2)(aa), and, thirdly, where the accused is absent from the proceedings without leave of the court (s 159(2)(b))". See p 667.

66 In $S v$ Shinga (Society of Advocates Pietermaritzburg Bar as Amicus Curiae) (AR969/2004) 2006 (KZHC) 12 (2006-08-03) par 11, where the court stated that " $[\mathrm{t}]$ he right to audience before a court, though sharing features in common with the right to a public trial, such as transparency of the proceedings and engendering confidence in the deliberations of the Court, also embodies some unique rights and privileges. Subject to the exceptional circumstances envisaged in Ss 158(2)-(4) \& s 159 of the CPA, s 158 provides for the presence of an accused person at his or her trial".

67 See submission by Dr CP Mulder, Debates of the National Assembly supra $n$ 48 at 4995 . 
applicable to a witness based abroad as it does to one based in South Africa, there is no compelling reason why it should not be applicable to an accused based abroad as it does to one based in South Africa. The effect would be that a person who is accused of an offence in South Africa, could give evidence at his trial by means of closed circuit television or similar electronic media while he is abroad. There would be no need to extradite him to South Africa to stand trial. If the court imposes a suspended sentence, it could even be enforced in his country on the basis of section $297 \mathrm{~B}$ of the Criminal Procedure Act. ${ }^{68}$ It is only when he is sentenced to imprisonment, that he would be required to serve his sentence in South Africa, in the light of the fact that South Africa is yet to sign a prisoner transfer agreement with any country or ratify any multilateral prisoner transfer treaty. ${ }^{69}$ There is nothing in the Hansard to suggest that that is what the legislators had in mind when they debated and passed section 158

It should also be recalled that unless otherwise provided for under legislation or common law, the powers of the National Director of Public Prosecutors and those of the prosecutors generally, "extend only to the borders of the country [South Africa]". ${ }^{78}$ Therefore, a South African prosecutor is generally not empowered to conduct prosecutorial activities outside South Africa. Applying section 158 of the Criminal Procedure Act to witnesses based abroad, would also be self-defeating as South African law does not govern witnesses in other countries. Another important issue is that before a witness gives evidence, he or she has to take an oath or affirm or be admonished to speak the truth. If he does not speak the truth, he could be prosecuted for the offence of perjury. ${ }^{71}$ If such a witness is based abroad, the only way to have him prosecuted in South Africa for perjury is to have him extradited to South Africa in

68 S 297B of the Criminal Procedure Act provides that "(1) The State President may, on such conditions as he may deem necessary, enter into an international agreement with any state, so as to provide, on a reciprocal basis, for the putting into operation of suspended sentences in respect of persons convicted, within the jurisdiction of the Republic or of such state, of an offence mentioned in the agreement. (2) The State President may, if the parties agree, amend such an agreement to the extent which he deems necessary. (3) If an application is made for a suspended sentence, imposed by a court of a state referred to in subsection (1), to be put into operation, the court at which the application is made shall, subject to the terms of the agreement, proceed with that application as if the suspended sentence was imposed by a court in the Republic. (4)(a) An agreement referred to in subsection (1), or any amendment thereof, shall only be in force after it has been published by the State President by proclamation in the Gazette. (b) The State President may at any time and in like manner withdraw any such agreement".

69 Mujuzi 'Towards the Establishment of a Prisoners Transfer Legal Regime in South Africa: Failed Attempts, Available Options and Critical Issues to Consider' 2012 AJICL 281-300.

70 Minister of Defence $v$ Potsane and another, Legal Soldier (Pty) Ltd and others $v$ Minister of Defence and others 2002 (1) SA 1 (CC); 2001 (11) BCLR 1137 par 24.

71 For a detailed discussion of the elements of the offence of perjury in South African law, see Snyman Criminal Law (2008) 343-347. 
terms of the Extradition Act. ${ }^{72}$ It is very unlikely that such a person would be extradited to South Africa. ${ }^{73}$

\section{Conclusion}

Section 158(2)-(4) empowers a South African court to order that a witness or an accused give evidence by means of closed circuit television. In many cases it has been invoked for a South Africa based witness to give evidence. Although there are judges who hold the view that section 158 is applicable only to witnesses based in South Africa, there are judges, including those of the Supreme Court of Appeal, who hold the opposite view. Those in the latter category have even gone so far as to invoke section 158(2)-(4) to receive evidence from witnesses based abroad.

Relying on the drafting history of the Criminal Procedure Amendment Act, and on other rules of statutory interpretation, the author has demonstrated that section 158(2)-(4) was not designed to deal with witnesses who are based abroad. It has been argued that a court in a criminal trial, which needs to rely on the evidence of a witness who is based abroad and whose presence in South African cannot be secured, has to invoke section 2(1) of the International Co-operation in Criminal Matters Act. The question that one has to answer is: What is the legal status of evidence obtained from abroad on the basis of section 158(2)(4)? It is submitted that such evidence is improperly or unlawfully obtained evidence. This is because it was obtained by invoking a wrong legal provision. The court will have to invoke its common law discretion to determine whether or not to admit such evidence. This would require it to determine whether the admission of such evidence would render the trial unfair or otherwise be detrimental to the administration of justice. If the answer to one of the legs in that test is in the affirmative, such evidence must be excluded. ${ }^{74}$

In deciding whether or not to admit evidence obtained from abroad, on the basis of section 158, courts should also consider the contribution of such evidence to the outcome of the trial. If it plays a vital role to the outcome of the trial, it should be excluded. However, there is a need for the courts, prosecutors and defence lawyers, where this has not happened, to appreciate that section 158 is not an avenue through which evidence may be obtained from abroad. Section 158 should not be used as a shortcut to avoid the process that has to be followed in terms of section 2(1) of the International Co-operation in Criminal Matters Act.

72 Act 67 of 1962 .

73 For a detailed discussion of the factors that have to be in place before a person is extradited to South Africa, see Dugard International Law: A South African Perspective (2005) 210-237.

74 See Schwikkard \& Van Der Merwe supra n 3 at 206-208; see also Zeffertt \& Paizes The South African Law of Evidence (2009) 716-718. 